\title{
Feeding patterns and predation potential of scyphomedusae in a highly productive upwelling region
}

\author{
Cynthia L. Suchman ${ }^{1,3, *}$, Elizabeth A. Daly ${ }^{2}$, Julie E. Keister ${ }^{2,4}$, William T. Peterson ${ }^{1}$, \\ Richard D. Brodeur ${ }^{1}$ \\ ${ }^{1}$ Northwest Fisheries Science Center, NOAA Fisheries, Newport, Oregon 97365, USA \\ ${ }^{2}$ Cooperative Institute for Marine Resources Studies, Hatfield Marine Science Center, Oregon State University, Newport, \\ Oregon 97365, USA \\ ${ }^{3}$ Present address: Virginia Institute of Marine Science, Gloucester Point, Virginia 23062, USA \\ ${ }^{4}$ Present address: School of Oceanography, University of Washington, Seattle, Washington 98195, USA
}

\begin{abstract}
We quantified diet and predation rates for large scyphomedusae from a coastal upwelling region. In the Northern California Current, early stages of euphausiids, gelatinous taxa, and cladocerans were particularly vulnerable to predation by Chrysaora fuscescens, Aurelia labiata, and Phacellophora camtschatica, whereas copepods were not. Moreover, C. fuscescens had the potential to deplete the standing stock of euphausiid eggs where predator and prey overlapped. During August 2002, C. fuscescens ingested an average $32.5 \%$ of the standing stock of euphausiid eggs each day at stations close to shore and north of Cape Blanco $\left(42.9^{\circ} \mathrm{N}, 126.6^{\circ} \mathrm{W}\right)$ where maximum abundances of the medusae occurred. Ingestion of other vulnerable prey, such as other early stages of euphausiids and gelatinous taxa, reached 10 to $12 \% \mathrm{~d}^{-1}$. In contrast, we calculated the maximum removal rate of the standing stock of copepods to be $<1 \% \mathrm{~d}^{-1}$. Given the importance of euphausiids to fish and other top predators, and the potential for changes in abundance and distribution of both predator and prey taxa with changes in climate, we suggest that gelatinous zooplankton abundance and predation impacts be incorporated within long-term studies and ecosystem models.
\end{abstract}

KEY WORDS: Gelatinous zooplankton - Coastal upwelling - Euphausiids - California Current · Scyphozoa $\cdot$ Aurelia $\cdot$ Chrysaora $\cdot$ Phacellophora

Resale or republication not permitted without written consent of the publisher

\section{INTRODUCTION}

Gelatinous zooplankton are ubiquitous in coastal ecosystems and can prey voraciously on co-occurring zooplankton and ichthyoplankton. Although the role of predators in influencing zooplankton community structure is well established for freshwater lakes (Brooks \& Dodson 1965), top-down effects are more difficult to establish as a primary factor structuring marine ecosystems. Nevertheless, several studies have shown inverse relationships between medusae and their prey (e.g. Möller 1984, Behrends \& Schneider 1995). Anthropogenic effects such as overfishing, eutrophication, introduction of alien species, and cli- mate change may lead to shifts to 'jelly' dominated communities in some areas (Purcell et al. 1999, Mills 2001, Purcell 2005, Lynam et al. 2006). We need to consider both changes in populations and predation impact of gelatinous predators if we hope to understand or predict marine ecosystem dynamics fully.

Most of what we know about jellyfish predation comes from studies of relatively small medusae in semi-enclosed bays or estuaries, or under experimental conditions. Gut content analyses of larger individuals (Graham \& Kroutil 2001, Purcell 2003, Uye \& Shimauchi 2005) show that, like smaller medusae, larger forms can feed across a broad range of zooplankton, including copepods, other gelatinous taxa, meroplank- 
ton and fish eggs. Reports on predation impact by large medusae vary widely. In the Bering Sea, Brodeur et al. (2002) estimated that Chrysaora melanaster consumed one-third of the standing stock of zooplankton during the summer season. In subregions of Prince William Sound, Alaska, Purcell (2003) calculated predation by scyphomedusae on copepod standing stock to be at most $0.3 \% \mathrm{~d}^{-1}$ and on larvaceans up to $7 \% \mathrm{~d}^{-1}$, although stations with the largest jellyfish aggregations were excluded from her analysis. Uye \& Shimauchi (2005) reported the Aurelia aurita population in the Sea of Japan could consume $26 \% \mathrm{~d}^{-1}$ of the available net zooplankton biomass.

This study quantifies diet and feeding rates for large medusae from a coastal upwelling region. These areas are known for exceptionally high seasonal productivity, and it has traditionally been assumed that most animal biomass is transferred though crustacean zooplankton and then fish via relatively direct trophic pathways. Nevertheless, gelatinous taxa, including large medusae, are consistently abundant in shelf regions of both the California Current (Shenker 1984, Suchman \& Brodeur 2005) and Benguela upwelling systems (Sparks et al. 2001, Lynam et al. 2006), with the summertime biomass of Chrysaora fuscescens off the Oregon coast reaching 50 to $65 \mathrm{mg} \mathrm{C} \mathrm{m}^{-3}$. Copepod biomass off Newport, Oregon in recent years has had summer peaks within the same order of magnitude ( $\sim 15$ to $50 \mathrm{mg} \mathrm{C} \mathrm{m}^{-3}$, Peterson et al. 2006). Given the high biomass of medusae in upwelling regions and their prodigious feeding rates in other geographic areas, it is reasonable to suggest that predation by medusae in upwelling systems may significantly impact zooplankton populations.

In this article we document predation patterns exhibited by large scyphomedusae that appear seasonally in the northern California Current. We present diet data for 3 species (Aurelia labiata, Chrysaora fuscescens, and Phacellophora camtschatica) and calculate feeding rates in relation to prey densities for C. fuscescens. Finally, using abundances of C. fuscescens and other zooplankton species collected throughout a broad region of the northern California Current during August 2002, we use our estimates of feeding rates to predict predation potential of C. fuscescens on the standing stock of the most common zooplankton taxa.

\section{MATERIALS AND METHODS}

Gut contents of medusae. During summer 2002 and 2003, we sampled 10 stations to collect 3 species of scyphomedusae (Chrysaora fuscescens, Aurelia labiata, and Phacellophora camtschatica) for gut content analysis or gut evacuation measurements. At the same time, we performed vertical net tows to assess the abundance and taxonomic composition of potential prey (Table 1, Fig. 1A).

Medusae were captured individually, either by divers (Stn 8, Fig. 1A) or from the deck of a research vessel (all other stations). At Stn 8, divers free-dove using a clear vinyl bag net on a pole to capture individual jellies, and while still under water, moved the jellyfish into individual plastic bags before removing them to the boat. Jellyfish near the surface were directly placed into bags. For other stations, we carefully dipped each medusa from the top 2 to $3 \mathrm{~m}$ of surface waters using a clear vinyl bag net with mesh bottom attached to a $4 \mathrm{~m}$ fiberglass extension pole. Those medusae analyzed for diet were preserved individually (immediately following capture) in a 21 container using a $5 \%$ buffered formalin solution; those used in gut evacuation experiments were placed in $19 \mathrm{l}$ buck-

Table 1. Chrysaora fuscescens, Aurelia labiata, Phacellophora camtschatica. Details for stations where scyphomedusae were collected for gut content analysis and summary of medusan size and gut contents. Stations are numbered in chronological order

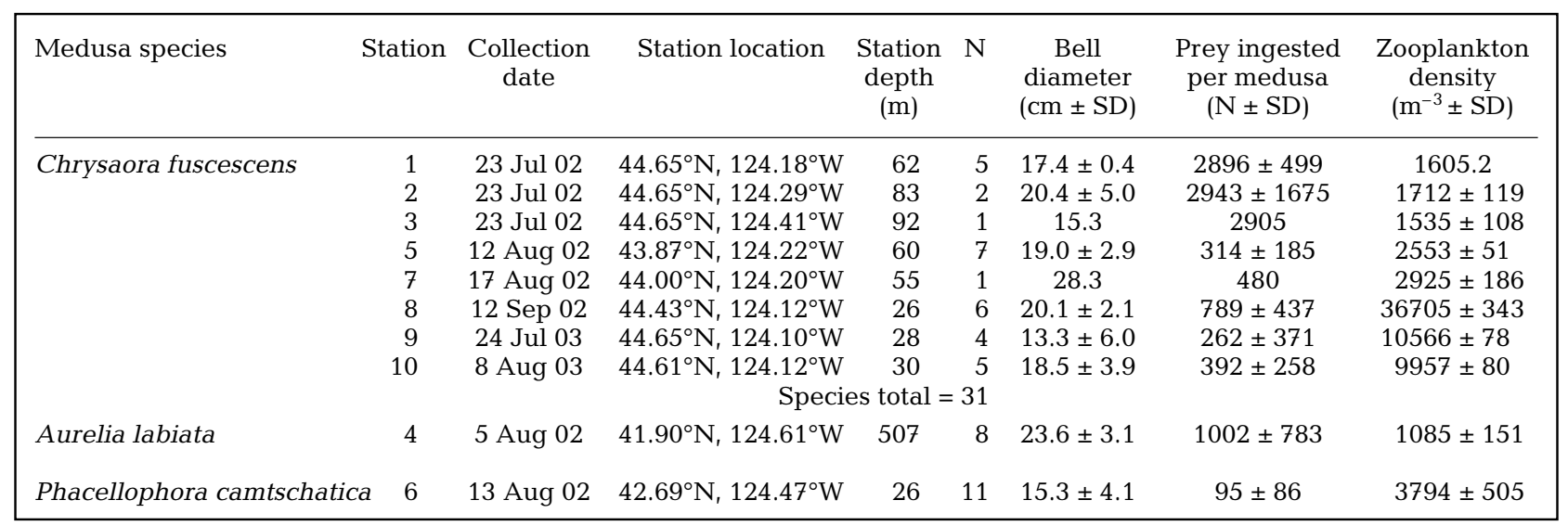



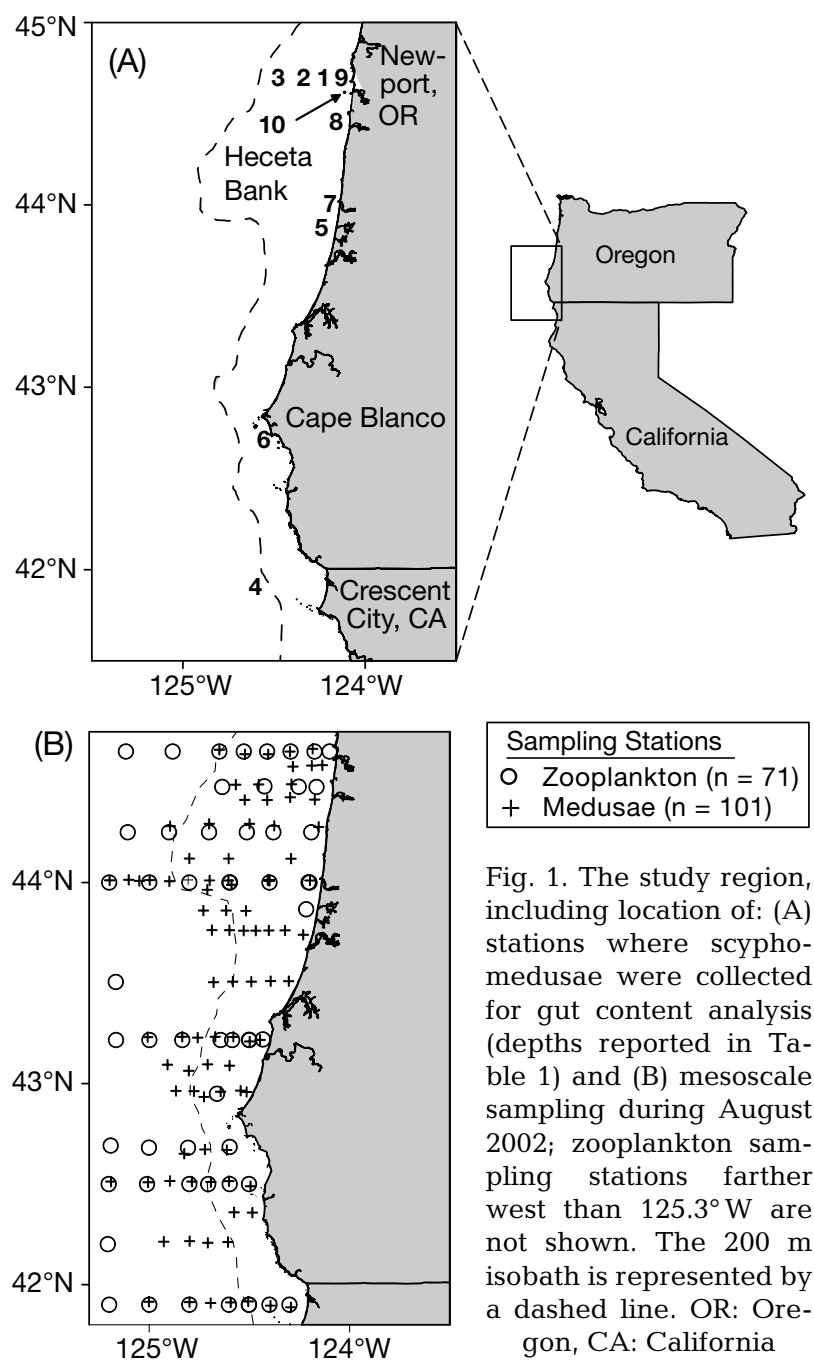
for gut content analysis (depths reported in Table 1) and (B) mesoscale sampling during August 2002; zooplankton sampling stations farther west than $125.3^{\circ} \mathrm{W}$ are not shown. The $200 \mathrm{~m}$ isobath is represented by a dashed line. OR: Oregon, CA: California

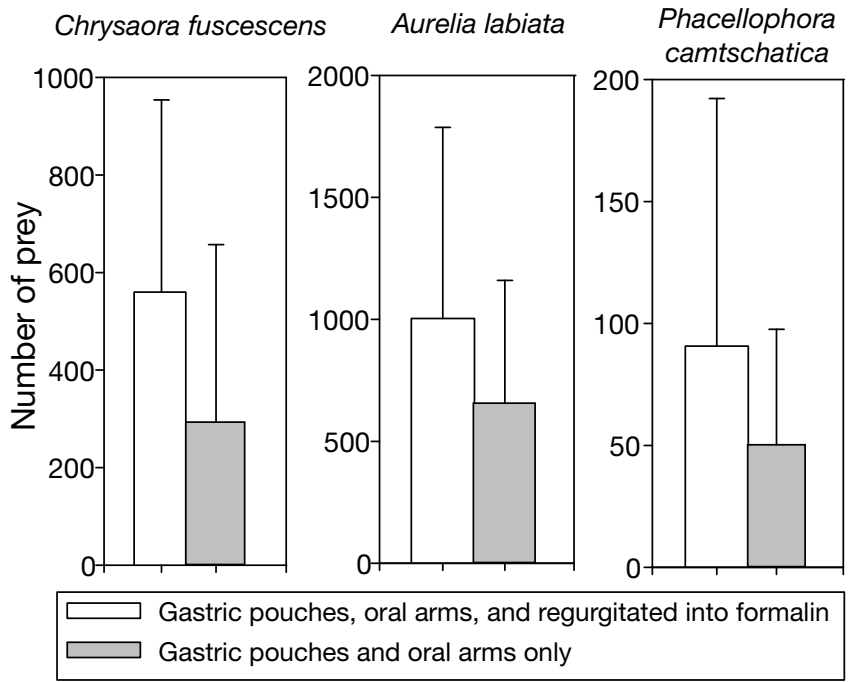

Fig. 2. Chrysaora fuscescens, Aurelia labiata, Phacellophora camtschatica. Difference between number of zooplankton recovered from gastric pouches and oral arms only, and number counted when zooplankton regurgitated into formalin preservative were included $(\mathrm{p}<0.05$, paired $t$-test for $C$. fuscescens and A. labiata, signed rank test for P. camtschatica where normality test failed). Number of medusae analyzed is available in Table 1. Values are means $\pm \mathrm{SD}$

ets containing filtered seawater for up to $6 \mathrm{~h}$ before they were preserved. In the laboratory (within $1 \mathrm{yr}$ of preservation) we determined gut contents of medusae by identifying and counting zooplankton present in gastric cavities, oral arms, and surrounding formalin. An average of $2 \mathrm{~d}$ of laboratory time per medusa was required to enumerate all ingested prey.

When live medusae are preserved in formalin, they regurgitate a significant proportion of the prey in their gut pouch and oral arms (Fig. 2). Loss rates averaged 34.5 to $51 \%$ (by species). In order to obtain accurate data on gastric contents at time of collection and variability between individuals, each medusa was preserved in a separate container, and all surrounding fluid was examined during enumeration of prey.

We did not measure size of living medusae used for gut content analysis because extra handling could cause loss of prey. Since medusae shrink when preserved in formalin, we quantified shrinkage through

repeated measurements of bell diameters of 10 Chrysaora fuscescens individuals not used for gut content analysis; first measurements were on live specimens, followed by 8 weekly measurements of the same group preserved in formalin. We discontinued measurements after 2 mo since diameter decreased after $1 \mathrm{~d}$ and remained stable thereafter. We used average shrinkage $(n=10)$ to estimate diameters of live medusae preserved for gut contents.

We sampled the zooplankton assemblage using a $50 \mathrm{~cm}$ diameter, $202 \mu \mathrm{m}$ mesh net towed vertically from $5 \mathrm{~m}$ above the sea floor to the surface $\left(30 \mathrm{~m} \mathrm{~min}^{-1}\right)$; at Stn 4 (depth $507 \mathrm{~m}$ ), we sampled the upper $100 \mathrm{~m}$. Volumes of water filtered (5.3 to $23.2 \mathrm{~m}^{3}$ ) were determined using readings from a calibrated TSK flowmeter. Zooplankton was preserved in $5 \%$ buffered formalin. At least two $1 \mathrm{ml}$ piston pipette subsamples were counted for each tow to determine zooplankton abundance (279 to 1783 zooplankters counted per station).

Gut evacuation experiments. To determine digestion times for prey items eaten by Chrysaora fuscescens, we measured gut evacuation rates twice: (1) 24 July 2003 at $\operatorname{Stn} 9\left(44.61^{\circ} \mathrm{N}, 124.12^{\circ} \mathrm{W}\right.$, surface temperature $7.5^{\circ} \mathrm{C}$ ) and (2) 8 August 2003 at Stn 10 $\left(44.65^{\circ} \mathrm{N}, 124.10^{\circ} \mathrm{W}\right.$, surface temperature $9.1^{\circ} \mathrm{C}$ ) (Table 1, Fig. 1A). Medusae dipped from surface waters were either preserved immediately in buffered formalin (time $=0$ ), or were placed in $19 \mathrm{l}$ containers 
filled with $80 \mu \mathrm{m}$-filtered seawater and maintained in darkness at ambient temperature for 2 to $6 \mathrm{~h}$. During Expt 1, C. fuscescens medusae were preserved after 0, 2,4 and $6 \mathrm{~h}$ ( $\mathrm{n}=2$ for each interval, except $\mathrm{n}=4$ at time $=0)$; medusae from Expt 2 were preserved after 2, 3,4 and $6 \mathrm{~h}$ ( $\mathrm{n}=2$ for each interval, except $\mathrm{n}=5$ at time $=0$ ). Throughout, we monitored medusae to be sure they continued pulsing normally.

We estimated digestion time by prey category for each trial by calculating linear regressions of average number of prey present at time zero through the earliest time that prey type was largely absent (average number $<20 \%$ than at time $=0$ ) (similar to Purcell 2003). The average of the $\mathrm{x}$-intercepts (time at prey $=$ 0 , from regression) of the 2 trials rounded to the nearest half hour was used as an estimate of digestion time.

We were careful to include only prey items that appeared to be digested by medusae in our analysis. Although bivalve veligers in Chesapeake Bay are able to survive ingestion by Chrysaora quinquecirrha by resisting digestion (Purcell et al. 1991), we saw bivalve and gastropod larvae in various stages of digestion in Chrysaora fuscescens gastric cavities. Therefore, we categorized these taxa as prey. In addition, the oral arms and gastric cavities of C. fuscescens and Phacellophora camtschatica were heavily parasitized by the amphipod Hyperia medusarum and occasionally by Cancer spp. megalopae. Since these taxa are known parasites of medusae, we excluded them from gut content analyses.

Prey selection. We used an electivity index (C) to compare feeding patterns among prey taxa and predator species, as this type of calculation allowed us to compare stations with variable prey distributions and test whether apparent differences in prey vulnerability are statistically significant. For each medusa, we determined Pearre's 'C' (Pearre 1982) for the most common prey taxa:

$$
\mathrm{C}=\left(\chi^{2} / \mathrm{N}\right)^{1 / 2}
$$

where $\chi^{2}$ tested for observed (in guts) versus expected (in environment) proportion of prey, and $\mathrm{N}=$ number of prey counted in gastric pouches + total number of zooplankton counted in subsamples of net tows. Values of ' $\mathrm{C}$ ' $\operatorname{span}-1$ to 1 (with -1 strongest selection against the prey type, 0 neutral, and 1 strongest selection for the prey type).

Counts of the numbers of zooplankton ingested (corrected for differences in digestion time among prey taxa; Sullivan et al. 1997) and zooplankton available in the environment (from counts of subsamples of net tows) were used to test for statistical significance using $\chi^{2}$. For Aurelia labiata and Phacellophora camtschatica, we assumed that the proportionate differences in digestion times for various prey taxa would be consistent with results from digestion experiments with
Chrysaora fuscescens. Other studies have shown that digestion time for a given prey type vary between predator species, but vary proportionately (Martinussen \& Båmstedt 1999, Suchman \& Sullivan 2000); therefore, we calculated prey selection indices, but not feeding rates, for A. labiata or $P$. camtschatica using digestion times for $C$. fuscescens.

Feeding rates and daily ration. We determined feeding rates by Chrysaora fuscescens on various zooplankton groups; we assumed that the $24 \mathrm{~h}$ feeding and digestion times for copepods were applicable to those crustacean taxa (including early stages of euphausiids) not present during gut evacuation measurements. Because medusae do not satiate at prey densities similar to or higher than those sampled during our study (Fancett \& Jenkins 1988, Båmstedt et al. 1994, Titelman \& Hansson 2006) and capture zooplankton based on prey vulnerability rather than active selection (Costello \& Colin 1994), we assumed that (1) feeding rates would vary linearly across all zooplankton densities and (2) feeding rates on each prey category would be independent of densities of alternative prey. Therefore, for each Chrysaora fuscescens dissected, ingestion over 24 h was calculated as:

$$
\begin{aligned}
& \text { Ingestion (no. prey d }{ }^{-1} \text { ) }= \\
& \text { [gut contents (no. prey)/digestion time }(\mathrm{h})] \times 24
\end{aligned}
$$

We ran multiple linear regressions to estimate feeding by Chrysaora fuscescens across zooplankton densities and medusa sizes within the study region.

In addition, for each medusa dissected, (1) carbon content (mg C) was calculated from its diameter using the conversions provided in Shenker (1985) and (2) daily carbon ingestion $\left(\mathrm{mg} \mathrm{C} \mathrm{d} \mathrm{d}^{-1}\right)$ was determined by multiplying ingestion rate and carbon content of each type of prey (Table 2), adding all prey types.

Mesoscale sampling of Chrysaora fuscescens and net zooplankton. Abundances and distributions of medusae and zooplankton were determined from 31 July to 19 August 2002 in the shelf and shelf-break region between $44.65^{\circ} \mathrm{N}$ and $41.90^{\circ} \mathrm{N}$ (off Newport, OR, USA to Crescent City, CA, USA) (Fig. 1B). Scientists on board the FV 'Frosti' collected medusae and nekton at 101 stations by towing a Nordic 264 rope trawl in surface waters for 30 min (Suchman \& Brodeur 2005). Net zooplankton were collected at 71 comparable stations on the RV 'New Horizon' as described previously. Contour maps summarizing abundance of Chrysaora fuscescens and copepods, early stages of euphausiids, and other gelatinous zooplankton in the region were generated using a Kriging interpolation algorithm in Surfer 8.0 (Golden Software, Inc.).

We estimated predation impact (fractional removal of standing stock $\mathrm{d}^{-1}$ ) of the Chrysaora fuscescens population at each station by multiplying the abundance of 
Table 2. Values used for carbon content of zooplankton prey

\begin{tabular}{|lcl|}
\hline Taxon & Mg C & \multicolumn{2}{c|}{ Source } \\
\hline Euphausiid eggs & 3.2 & Gómez-Gutiérrez (2003) \\
Euphausiid larvae & 6 & Ross (1982) \\
Calanoid copepods & 5 & Martinussen \& Båmstedt (1995) \\
Cyclopoid copepods & 1 & Martinussen \& Båmstedt (1995) \\
Molluscs & 0.2 & Martinussen \& Båmstedt (1995) \\
Gelatinous taxa & 2 & Martinussen \& Båmstedt (1995) \\
Polychaetes & 4 & Uye (1982) \\
Cladocerans & 1 & Martinussen \& Båmstedt (1995) \\
\hline
\end{tabular}

C. fuscescens (from trawls) by feeding rate from linear regressions, given known zooplankton densities (from plankton net tows):

Fraction zooplankton consumed $\mathrm{d}^{-1}=$ (medusae $\mathrm{m}^{-3} \times$ zooplankton medusa ${ }^{-1} \mathrm{~d}^{-1}$ ) / zooplankton $\mathrm{m}^{-3}$

For the stations where zooplankton counts were not available to pair with $C$. fuscescens abundance, zooplankton densities for target taxa were interpolated using the zooplankton contour map (30 stations).

\section{RESULTS}

We grouped net zooplankton into categories: (1) euphausiid eggs, (2) euphausiid nauplii and calyptopes, (3) calanoid copepods (adult and copepodite stages), (4) cyclopoid copepods (adults and copepodites), (5) molluscs, (6) gelatinous taxa, (7) polychaetes, (8) cladocerans, and (9) 'other.' For digestion experiments and feeding rate regressions, all copepods were grouped together. Euphausiids were Euphausia pacifica and Thysanoessa spinifera, both broadcast spawners. Calanoid copepods included the genera Acartia, Aetideus, Calanus, Candacia, Centropages, Clausocalanus, Eucalanus, Lucicutia, Metridia, Paracalanus, Pseudocalanus, Rhincalanus, Scolecithricella, and Tortanus. Cyclopoids were primarily Oithona, but Corycaeus was also consumed. Molluscs were bivalve larvae, gastropod larvae, and pteropods. Polychaetes were primarily larvae of benthic taxa. Gelatinous taxa included primarily larvaceans but also ctenophores, hydromedusae, salps, doliolids, and siphonophores.

\section{Digestion experiments}

Average gut evacuation time for various zooplankton groups ranged from 3 to $9 \mathrm{~h}$ (Fig. 3), with softer-bodied taxa disappearing from Chrysaora fuscescens gastric pouches and oral arms most quickly and molluscs least quickly. Gelatinous zooplankton averaged $3 \mathrm{~h}$, polychaetes $4.5 \mathrm{~h}$, copepods $6 \mathrm{~h}$ and molluscs $9 \mathrm{~h}$.

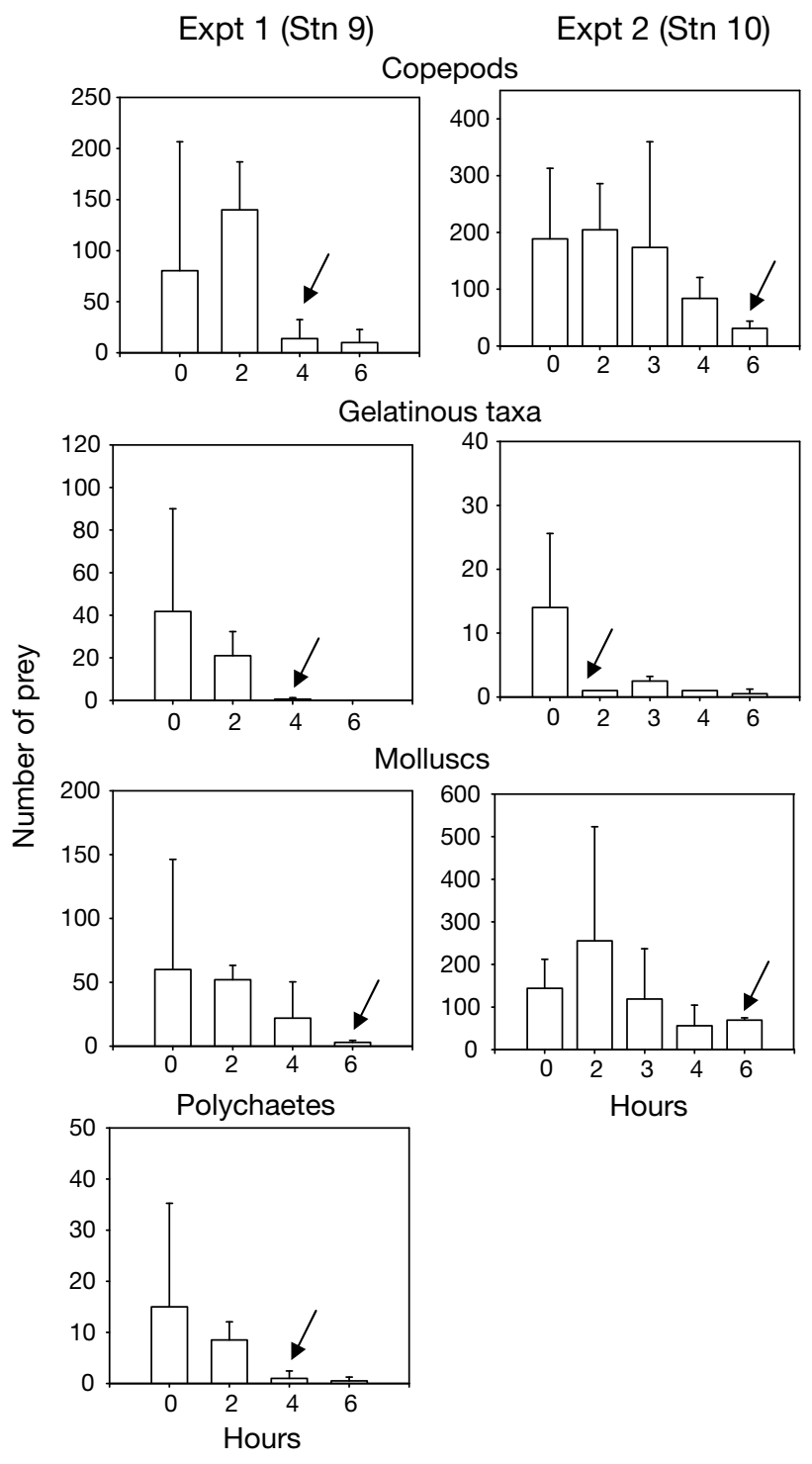

Fig. 3. Chrysaora fuscescens. Rate of disappearance of zooplankton from medusan guts, with full gut pouch at hour $=0$. Medusae used in Expt 1 were collected from Stn 9 (surface temperature $7.5^{\circ} \mathrm{C}$ ); those in Expt 2 were collected from Stn 10 (surface temperature $9.1^{\circ} \mathrm{C}$ ). Arrows denote time used for linear regression with $t=0$ (with digestion time estimated where $\mathrm{x}=0$ ). Scale differs for both axes among experiments and prey types. See Table 1 for stations. Values are means $\pm \mathrm{SD}$

\section{Diet analysis}

Chrysaora fuscescens individuals from 8 stations showed similar feeding habits, and in each case ingested zooplankton in proportions different from those available in the water column (Fig. 4). At all stations, calanoid copepods dominated the net zooplankton assemblage (42.7 to $78.0 \%$ ), with cyclopoids also often abundant. At Stn 8, 'other' species was the 
second most abundant group, comprising primarily copepod nauplii $(29.4 \%$ of net zooplankton) and barnacle nauplii ( $7.4 \%$ of net zooplankton), though both of these were likely undersampled by the $202 \mu \mathrm{m}$ net. Copepods were not ingested in proportion to their abundance in the plankton. Instead, when euphausiid eggs $(\sim 400 \mu \mathrm{m})$ were present in the water column, even at relatively low densities (Stns 1, 2, 3, 5, and 7; 4.4 to $11.5 \%$ of total zooplankton), they were the largest component of the diet of C. fuscescens (32.8 to $91.5 \%$ of diet). When euphausiid eggs were absent,

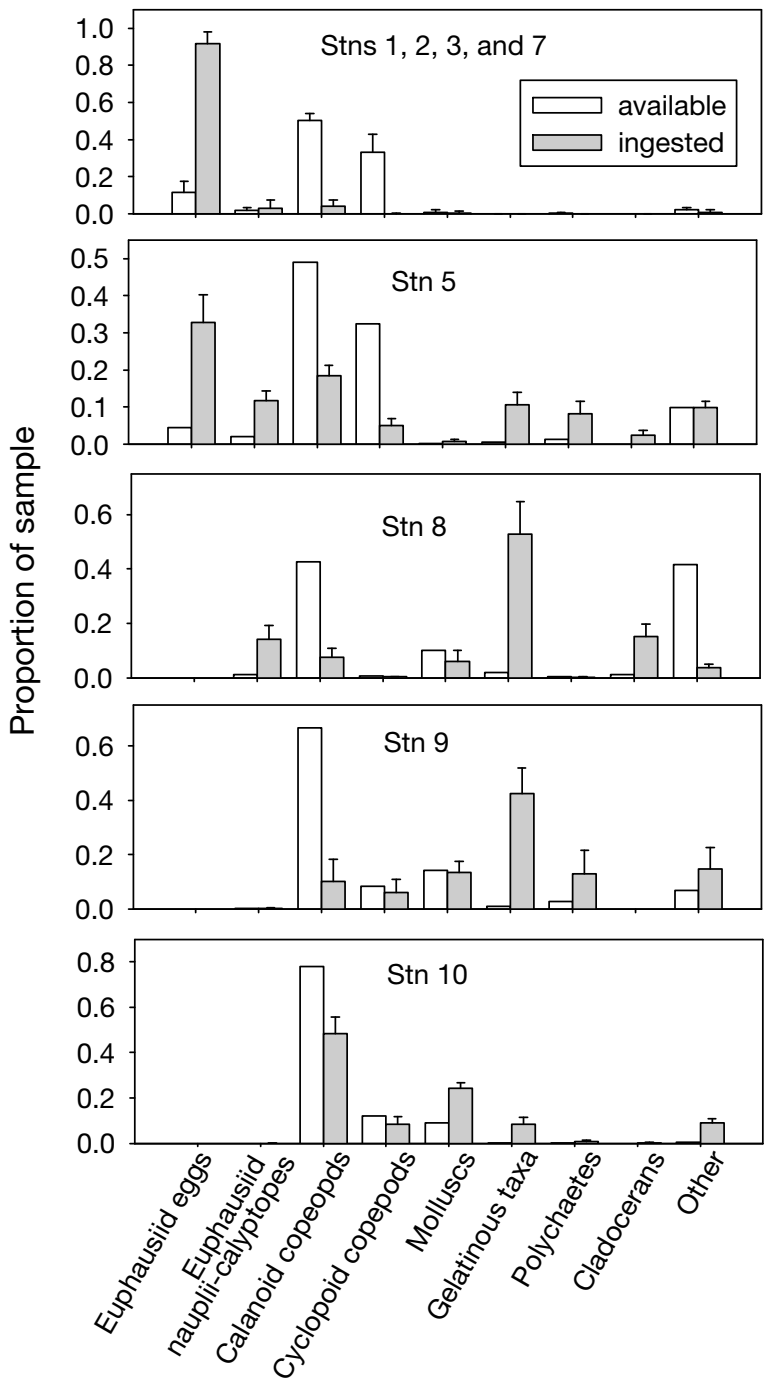

Fig. 4. Chrysaora fuscescens. Proportion of zooplankton available vs proportion ingested by medusae, by station. Ingested data have been corrected for differences in digestion time among prey types. Data from Stns 1, 2, 3, and 7 were aggregated as zooplankton prey fields were similar (SD represents variability among medusan gut contents or counts from plankton tows). Details on numbers of medusae analyzed and zooplankton densities are available in Table 1, as is the list of stations. Values are means $\pm \mathrm{SD}$ gelatinous zooplankton were the prey type most consumed (Stns 8 and 9). Only at Stn 10, with no early stages of euphausiids and almost no gelatinous zooplankton available, were calanoid copepods the primary prey group ingested by $C$. fuscescens.

Results for Phacellophora camtschatica and Aurelia labiata were similar in that copepods, despite their availability in the plankton ( 70.1 to $73.8 \%$ ), were not the primary prey ingested by medusae (Fig. 5). Aurelia labiata ingested mostly euphausiid eggs $(7.8 \%$ in plankton, $61.6 \%$ ingested), and P. camtschatica ingested gelatinous taxa ( $11.1 \%$ in plankton, $65.9 \%$ ingested).

Applying a correction to gut contents to account for differences in digestion time among prey types refined, but did not alter, overall feeding patterns. At some stations, ingestion patterns were nearly identical with or without a digestion correction $(<1 \%$ change for all prey types, Stns 1, 2, 3 and 7). Similarly, at all stations, proportion of euphausiid eggs and copepods changed little (maximum $6 \%$ change for euphausiid eggs and $4 \%$ for copepods). Fast digestion time for gelatinous zooplankton did increase the relative proportion of these animals in the diet of scyphomedusae in some cases, particularly at Stns 6, 8, and 9, where uncorrected diet had fewer gelatinous organisms (uncorrected diet: $24 \%$, $18 \%$, and $16 \%$ respectively) (Figs. 4 \& 5). Even so, overall feeding pattern remained the same. Because this and other studies (e.g. Purcell 2003) have demonstrated relatively fast digestion times for soft-bodied taxa, the digestion correction should provide the most accurate view of feeding patterns.

When electivities for individual medusae were averaged (significant values of Pearre's ' $\mathrm{C}$ ', by medusa; $\chi^{2}$, $\mathrm{p}<0.05)$, general feeding patterns became clear

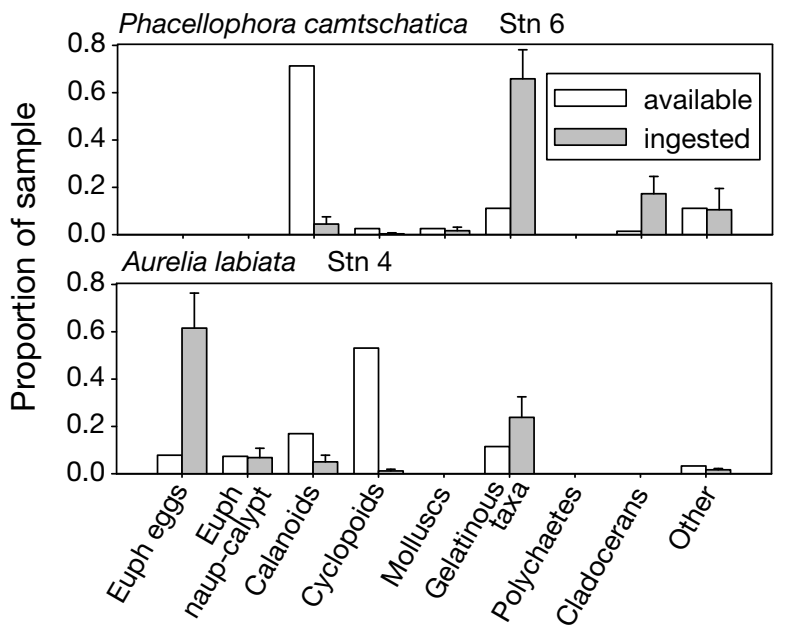

Fig. 5. Phacellophora camtschatica, Aurelia labiata. Proportion of zooplankton available vs ingested by medusae, by station. Details regarding number of medusae analyzed and zooplankton densities are available in Table 1, as is the list of stations. Values are means $\pm \mathrm{SD}$ 


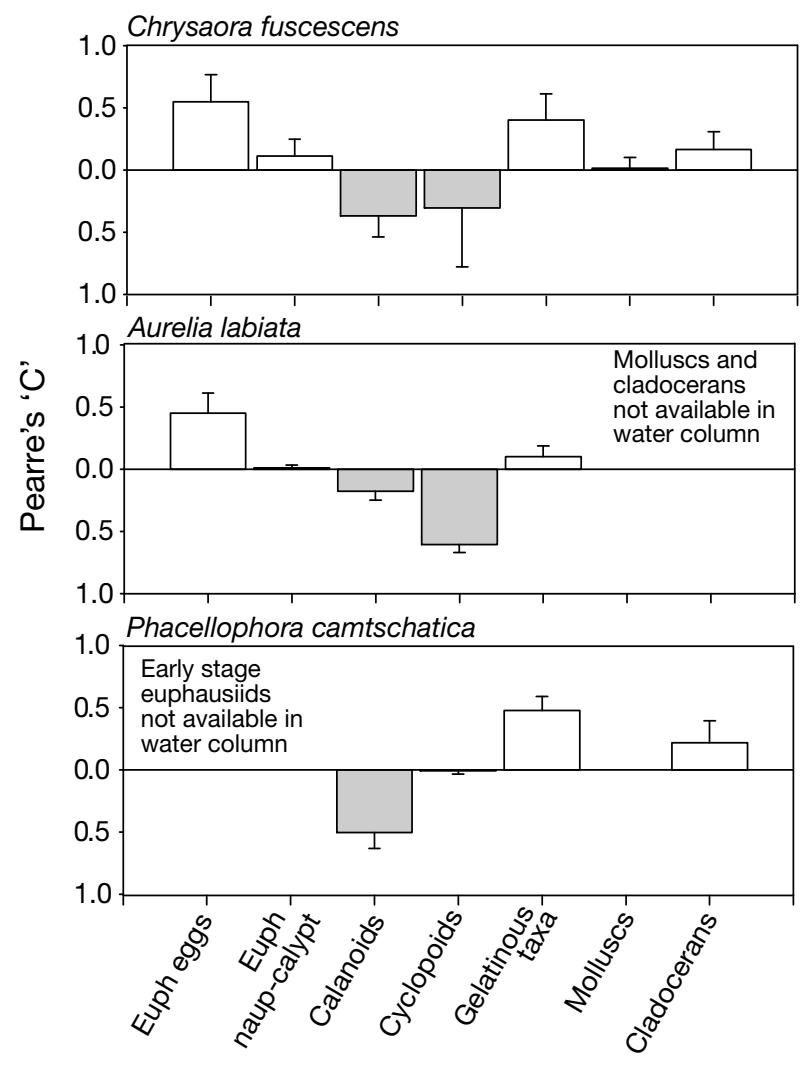

Fig. 6. Chrysaora fuscescens, Aurelia labiata, Phacellophora camtschatica. Feeding summarized by averaging significant electivity values $\left(\chi^{2}, \mathrm{p}<0.05\right)$ of Pearre's ' $\mathrm{C}$ ' for zooplankton prey categories, using 0 when ' $\mathrm{C}$ ' was not significant (neutral selection). Pearre's ' $\mathrm{C}$ ' ranges from -1 to 1 , with positive values indicating selection for highly vulnerable prey and negative values selection against prey type. Sample sizes are available in Table 1. euph: euphausiid; naup calypt: naupliicalyptopes. Values are means \pm SD

(Fig. 6). When euphausiid eggs and gelatinous taxa were present in the plankton, they were preferentially ingested by medusae. Cladocerans were also positively selected, but less strongly than euphausiid eggs or gelatinous taxa. Copepods were consistently negatively selected. $\mathrm{cm}$, with averages of 13.3 to $28.3 \mathrm{~cm}$ per station. Preserved medusae were $0.85 \pm 0.02$ (SD) of the live size. Numbers of prey ingested by each medusa ranged from 39 to 5329, with averages of 262 to 2943 medusa $^{-1}$ by station (Table 1 ).

Medusae dissected ingested an average of $1.3 \%$ of their carbon content $\mathrm{d}^{-1}$, with no significant differences between average daily ration at stations with and without euphausiid eggs present as prey (Table 3 ).

To account for differential prey vulnerability, we separated zooplankton into groups for linear regressions: (1) euphausiid eggs, (2) other naupliar and calyptopes larval stages of euphausiids, (3) copepods, and (4) gelatinous zooplankton (Table 4). Feeding rates on copepods could not be estimated using linear regression ( $p>0.05)$. Regressions for other taxa, though significant, had adjusted $r^{2}$ values of 0.70 at most, indicating high variability among individuals or unidentified covariates. Medusa diameter was never a

Table 3. Chrysaora fuscescens. Average carbon content of medusa and gastric contents, by station. Numbers of medusae dissected and prey counted available in Table 1, and carbon conversions in Table 2

\begin{tabular}{|cccc|}
\hline Stn & $\begin{array}{c}\text { mg C medusa } \\
( \pm \mathrm{SD})\end{array}$ & $\begin{array}{c}\mathrm{mg} \mathrm{C} \mathrm{d}^{-1} \text { ingested } \\
( \pm \mathrm{SD})\end{array}$ & $\begin{array}{c}\% \mathrm{C} \mathrm{d}^{-1} \\
( \pm \mathrm{SD})\end{array}$ \\
\hline 1 & $1552 \pm 860$ & $38 \pm 22$ & $2.7 \pm 0.9^{\mathrm{a}}$ \\
2 & $1033 \pm 73$ & $41 \pm 8$ & $3.9 \pm 0.4^{\mathrm{a}}$ \\
3 & 672 & 37 & $5.6^{\mathrm{a}}$ \\
5 & $1303 \pm 490$ & $5 \pm 3$ & $0.4 \pm 0.2^{\mathrm{a}}$ \\
7 & 2906 & 6 & $0.2^{\mathrm{a}}$ \\
8 & $1490 \pm 368$ & $10 \pm 6$ & $0.6 \pm 0.3$ \\
9 & $1084 \pm 860$ & $4 \pm 4$ & $0.4 \pm 0.04$ \\
10 & $1226 \pm 671$ & $4 \pm 3$ & $0.4 \pm 0.2$ \\
\multicolumn{4}{c}{ All medusae } \\
Euphausiid eggs present & $1.3 \pm 1.5 \pm 1.8$ \\
a Ntations where euphausiid eggs were present. Differ- \\
ences between medusae from stations with or without \\
euphausiid eggs were not significant (Mann-Whitney \\
test, p > 0.05)
\end{tabular}

\section{Feeding rates and predation impact}

We limited our analysis of feeding rate to Chrysaora fuscescens because it was the only species of medusa for which we had adequate data (number of individuals $=31$, and number of stations $=8$; Table 1). Zooplankton densities by station ranged from 1535 to $36705 \mathrm{~m}^{-3}$. Live bell diameters of $C$. fuscescens ranged from 10.6 to 28.3
Table 4. Chrysaora fuscescens. Simple linear regression of feeding rate as a function of prey density for specific zooplankton groups, with $y=$ feeding rate by a single medusa $\left(\mathrm{d}^{-1}\right)$ and $x=$ density of zooplankton prey $\left(\mathrm{m}^{-3}\right)$. Medusa diameter was not a significant covariate. $n s=$ not significant $(\mathrm{p}>0.05)$. Sample sizes are available in Table 1 and prey proportions in Figs. $4 \& 5$

\begin{tabular}{|lccc|}
\hline Zooplankton group & p-value & Model & $\mathrm{r}^{2}$ adjusted \\
\hline Euphausiid eggs & $<0.001$ & $y=(-1.6)+30.2(x)$ & 0.428 \\
Euphausiid nauplii-calyptopes & 0.008 & $y=120.2+1.2(x)$ & 0.189 \\
Calanoid and cyclopoid copepods & $\mathrm{ns}$ & $\begin{array}{c}\text { average }=377 \pm 330 \\
y=45.4+2.7(x)\end{array}$ & 0.7 \\
Gelatinous zooplankton & $<0.001$ & $y=4.7$ \\
\hline
\end{tabular}




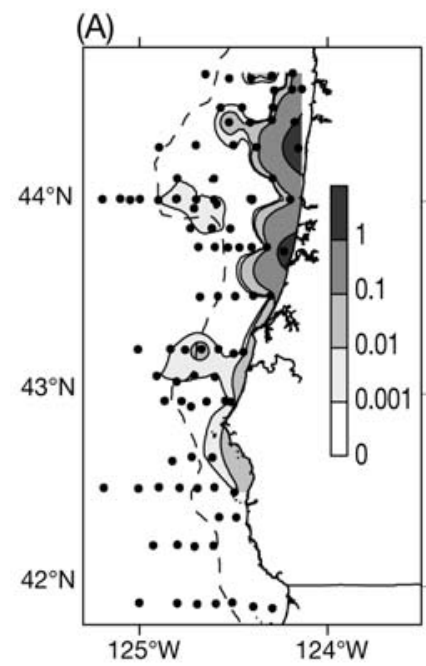

(B)

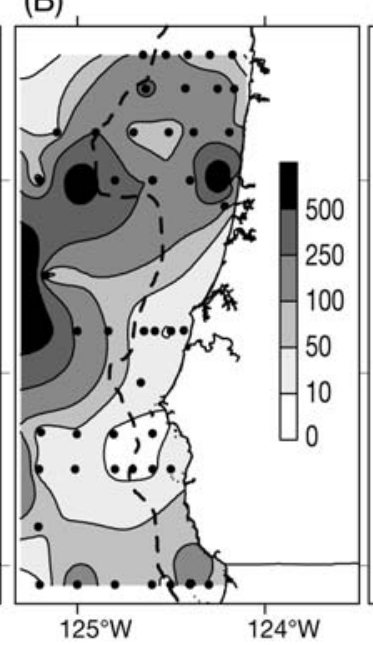

(C),

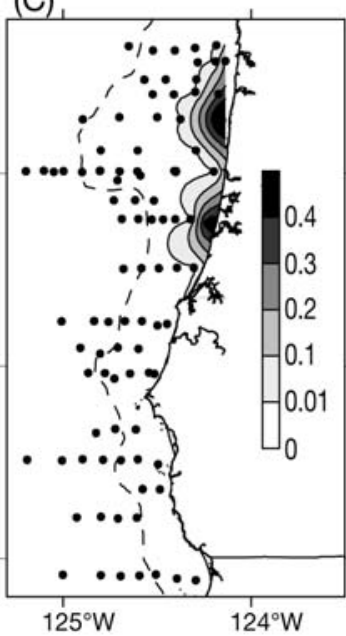

Fig. 7. Chrysaora fuscescens and Euphausiidae. (A) Abundance (no. $100 \mathrm{~m}^{-3}$ ) and distribution of $C$. fuscescens collected in surface trawls during August 2002. C. fuscescens medusae were present in $55 \%$ of trawls in the region (Suchman \& Brodeur 2005), with highest abundances near the coast and north of Cape Blanco. (B) Abundance (no. $\mathrm{m}^{-3}$ ) and distribution of euphausiid eggs collected in vertical tows during August 2002. (C) Predation potential of C. fuscescens on standing stock of euphausiid eggs during August 2002 (fractional removal of standing stock $\mathrm{d}^{-1}$ ). Maximum predation pressure coincided with highest abundances of C. fuscescens, reaching $60 \% \mathrm{~d}^{-1}$ and averaging $32.5 \% \mathrm{~d}^{-1}$ nearshore and north of $43.5^{\circ} \mathrm{N}$. - - - : shelf break (200 $\mathrm{m}$ isobath). •: locations of surface trawls (A \& C) or plankton tows (B) significant covariate, although it may have been had we used a larger sample size encompassing a wider range of bell diameters (e.g. Purcell 2003).

We used abundances of Chrysaora fuscescens and zooplankton to estimate trophic impact of the C. fuscescens population throughout the study region during August 2002. C. fuscescens medusae were present in $55 \%$ of trawls (Suchman \& Brodeur 2005), with maximum abundance of 2 individuals $100 \mathrm{~m}^{-3}$ along the inner continental shelf north of Cape Blanco (Fig. 7A). Because medusae analyzed for gut contents had highest feeding rates on euphausiid eggs (up to 20920 eggs d $^{-1}$ ), we expected to see the largest impact on this zooplankton group. Except for one nearshore area at $44^{\circ} \mathrm{N}$, the highest densities of eggs (up to $1092 \mathrm{~m}^{-3}$, from counts of net tows) were found offshore from the shelf break in areas spatially separated from C. fuscescens (Figs. 7B \& 8). Where medusae were most abundant, they removed an average of $32.5 \%$ and up to $60 \% \mathrm{~d}^{-1}$ of the standing stock of euphausiid eggs (Tables $5 \& 6$, Fig. 7C). In contrast, the calculated maximum removal rates of the standing stocks of copepods (using average feeding rate across copepod densities, Table 4), gelatinous taxa and euphausiid nauplii, metanauplii, and calyptopes were $<1,10.5$ and $12.2 \%$ $\mathrm{d}^{-1}$, respectively (Table 5). As with euphausiid eggs, predation impact was highest in nearshore areas where C. fuscescens were most abundant (Fig. 9). Copepods, the prey category least vulnerable to predation by $C$. fuscescens, had highest densities along the inner shelf, coinciding with the predator's population maximum (Figs. $7 \& 9$ ).

\section{DISCUSSION}

Our results suggest (1) differential vulnerability of zooplankton prey to scyphomedusae of the Northern California Current, with early stages of euphausiids and gelatinous taxa particularly vulnerable to predation (Fig. 6), and (2) a potential for depletion of the standing stock of euphausiid eggs in the nearshore zone at times and locations when medusae are most abundant (Table 6, Fig. 7). Chrysaora fuscescens in August 2002 was restricted to more northern, nearshore areas of the study region (Suchman \& Brodeur 2005), so predation on populations of Euphausia pacifica and Thysanoessa spinifera over seasonal and interannual time periods is likely to be focused in these shallow areas close to shore. Other medusae in the region may also ingest euphausiid eggs, so we have likely underestimated the impact of gelatinous predators on euphausiid popula-

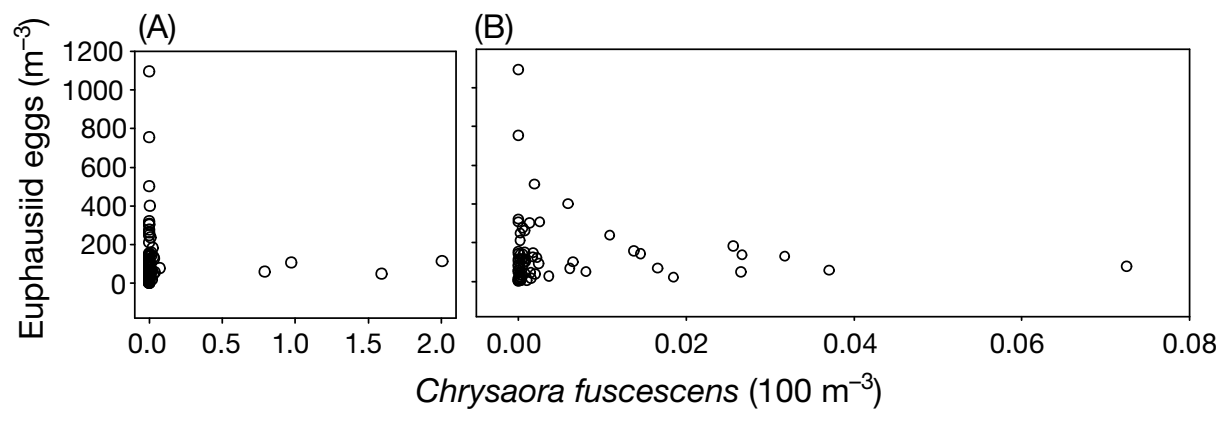

Fig. 8. Chrysaora fuscescens. Relationship between abundance of $C$. fuscescens and euphausiid eggs at mesoscale sampling stations (Fig. 1). (A) Includes all stations; (B) shows same data without 4 stations having highest abundance of C. fuscescens 
Table 5. Chrysaora fuscescens. Summary of predation impact at $44.45^{\circ} \mathrm{N}, 124.19^{\circ} \mathrm{W}$, a mesoscale sampling station with highest abundance of $C$. fuscescens (2 medusae $100 \mathrm{~m}^{-3}$ )

\begin{tabular}{|c|c|c|}
\hline Prey taxa & $\begin{array}{l}\text { Prey ingested } \\
\left(\text { no. } \mathrm{m}^{-3} \mathrm{~d}^{-1}\right)\end{array}$ & $\begin{array}{l}\% \text { standing } \\
\text { stock d }^{-1}\end{array}$ \\
\hline Euphausiid eggs & 69 & 60.6 \\
\hline $\begin{array}{l}\text { Euphausiid nauplii, } \\
\text { metanauplii, calyptopes }\end{array}$ & 3 & 12.2 \\
\hline Gelatinous zooplankton & 2 & $9.7^{\mathrm{a}}$ \\
\hline Copepods & $7^{b}$ & 0.5 \\
\hline
\end{tabular}

tions. In addition, distribution and abundance of predators and prey can shift with climatic (Peterson et al. 2002, Lynam et al. 2004), hydrographic (Keister et al. 2000), or anthropogenic factors (Mills 2001, Purcell et al. 1999), and these shifts have the potential to intensify trophic interactions.

Diets of Chrysaora fuscescens, Aurelia labiata, and Phacellophora camtschatica were similar (Fig. 6).
Table 6. Chrysaora fuscescens and Euphausiidae. Summary of average predation rates $\left(\% \mathrm{~d}^{-1}\right)$ on euphausiid eggs by C. fuscescens according to geographic location, with $\mathrm{n}=$ number of stations. Highest impact was in shallow, nearshore areas in the northern part of the study region. Predation impact in other areas was negligible

\begin{tabular}{|lcc|}
\hline \multirow{2}{*}{$\begin{array}{l}\text { Station depth } \\
(\mathrm{m})\end{array}$} & \multicolumn{2}{c|}{ \% euphausiid eggs ingested $\mathrm{d}^{-1}( \pm \mathrm{SD})$} \\
& North of $43.5^{\circ} \mathrm{N}$ & South of $43.5^{\circ} \mathrm{N}$ \\
\hline$<50$ & $32.5 \pm 23.2(\mathrm{n}=5)$ & $0.02 \pm 0.02(\mathrm{n}=4)$ \\
$50-100$ & $0.5 \pm 0.6(\mathrm{n}=18)$ & $0.01 \pm 0.02(\mathrm{n}=8)$ \\
$>100$ & $0.03 \pm 0.08(\mathrm{n}=38)$ & $0.03 \pm 0.1(\mathrm{n}=27)$ \\
\hline
\end{tabular}

These results are not surprising, given feeding mechanics of medusae. Gut contents integrate across fine and intermediate-scale prey patchiness as these large animals swim through their feeding environment, accumulating prey during the several hours it takes to digest them (Hansson \& Kiørboe 2006). Moreover, the term 'prey selection' should be understood as the effect of differential vulnerability of prey to encounters rather than the outcome of active pursuit by the predator. Previous studies of interactions between scypho-
Fig. 9. Chrysaora fuscescens and zooplankton prey. Abundance (no. $\mathrm{m}^{-3}$ ) and distribution of (A) copepods, (B) gelatinous zooplankton, and (C) euphausiid nauplii and calyptopes, collected by vertical net tows $(\bullet)$ during August 2002. Predation potential of $C$. fuscescens on standing stock of (D) copepods, (E) gelatinous zooplankton, and (F) euphausiid nauplii and calyptopes during August 2002 (fractional removal of standing stock $\mathrm{d}^{-1} ; \bullet$ : locations of trawls used to determine abundance of medusae). Maximum predation pressure coincided with highest abundances of $C$. fuscescens (see Fig. 7A). ---: shelf break (200 $\mathrm{m}$ isobath)
(A)

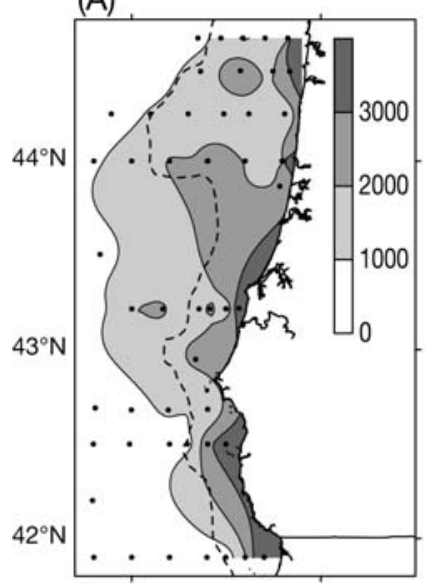

(D)

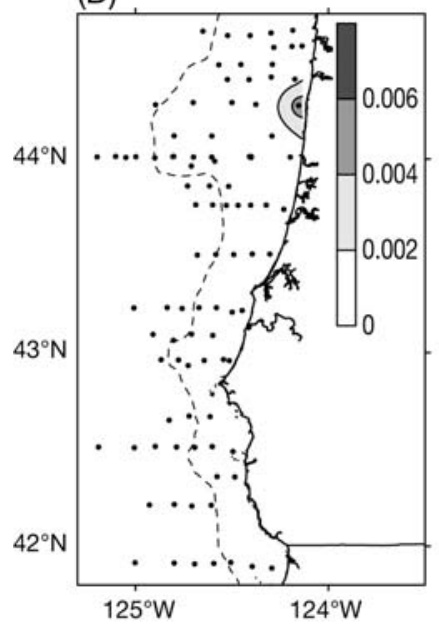

(B)

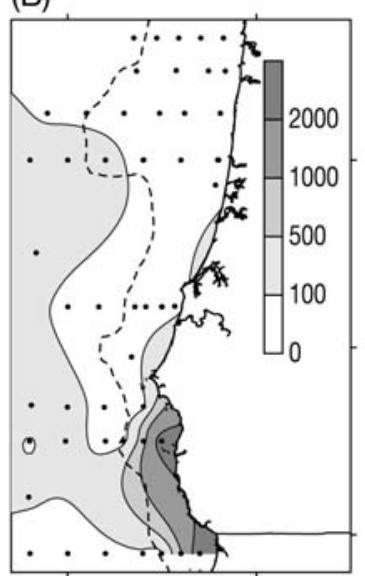

(E)

(C)
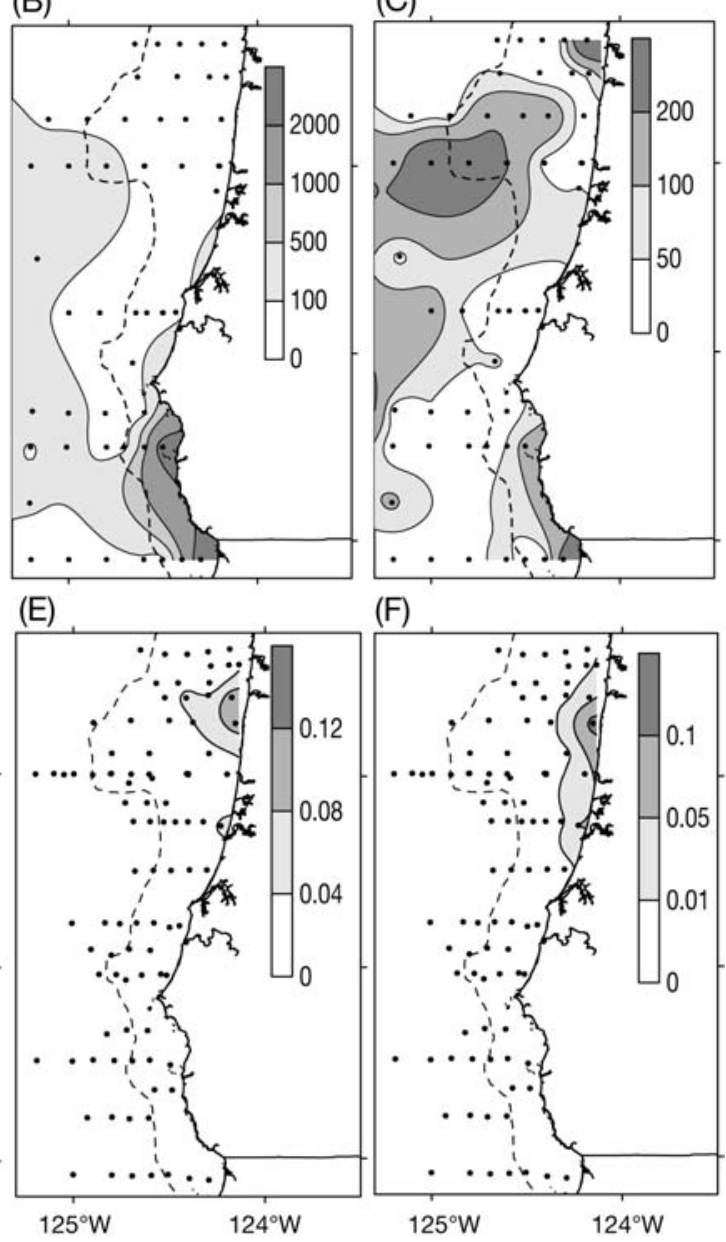

(F)

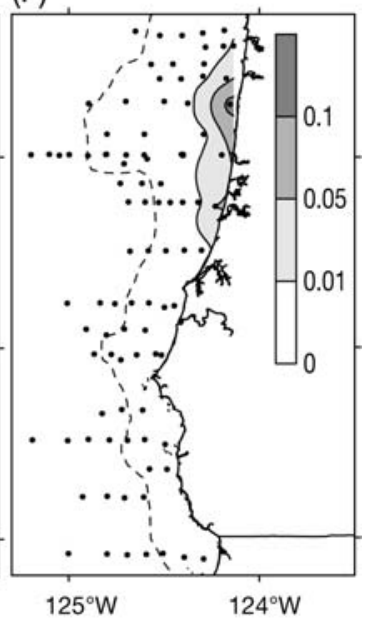


medusae and zooplankton have suggested that in general, larger, slow-escaping prey will be most vulnerable (Suchman \& Sullivan 2000) because they are more readily entrained in the flow created by a swimming medusa (Costello \& Colin 1994). This study supports this hypothesis, with selection for relatively slow taxa (early stages of euphausiids, gelatinous zooplankton, cladocerans) and selection against organisms that detect and respond to fluid disturbance quickly (copepods) (e.g. Fields \& Yen 1997). Euphausiid eggs are relatively large and have no ability to escape, making them particularly vulnerable to ingestion following encounters with medusae.

Based upon feeding patterns and ingestion rates reported here, copepod populations in the Northern California Current were not subject to heavy predation by Chrysaora fuscescens during August 2002. Predation on standing stock was always $<1 \% \mathrm{~d}^{-1}$ (Fig. 9). Similarly, in the central Baltic Sea, predatory impact of medusae on copepods was 0.06 to $1.15 \% \mathrm{~d}^{-1}$ (Barz \& Hirche 2005). In Prince William Sound, Alaska, medusae ingested at most $0.3 \% \mathrm{~d}^{-1}$ of the copepod standing stock (Purcell 2003). In each case, medusae removed other zooplankton prey items (early stages of euphausiids, cladocerans, larvaceans) at higher rates than copepods.

When euphausiid eggs were present, they constituted most of the prey items found in guts of both Chrysaora fuscescens and Aurelia labiata (Figs. 4 \& 5). At stations close to shore and north of Cape Blanco, where Chrysaora fuscescens were most abundant, medusae ingested an average of $32.5 \%$ and up to $61 \%$ of the standing stock of euphausiid eggs each day (Tables $5 \& 6$, Fig. 7). At the same stations, ingestion of other vulnerable prey (naupliar and calyptopis stages of euphausiids, and gelatinous taxa) reached 10 to $12 \% \mathrm{~d}^{-1}$. The estimate of $61 \% \mathrm{~d}^{-1}$ is not an artifact of pairing relatively high densities of medusae with low densities of euphausiid eggs. The highest densities of medusae ( 2 individuals $100 \mathrm{~m}^{-3}$ ) would be capable of ingesting 660 eggs $\mathrm{m}^{-3} \mathrm{~d}^{-1}$ or $60 \% \mathrm{~d}^{-1}$ at the station with highest density of eggs $\left(1092 \mathrm{~m}^{-3}\right)$ (Table 5).

Fig. 8 suggests an inverse relationship between density of euphausiid eggs and Chrysaora fuscescens, at least where medusae or eggs were most abundant. Even though factors such as predation by other taxa, advection or retention, and spawning frequency and location will also contribute to distribution of euphausiid eggs, in August 2002, densities of eggs were highest at stations with relatively few C. fuscescens medusae. In particular, the one nearshore station north of Cape Blanco with high euphausiid egg densities (at $44^{\circ} \mathrm{N}$, Fig. 7B) coincided with a local minimum of C. fuscescens (Fig. 7A).
Because we were unable to measure digestion time of euphausiid eggs, we need to be confident that our estimate is reasonable, particularly as relatively few data are available for such large medusae or from field studies where euphausiid eggs would be abundant. Clearance rates for Chrysaora fuscescens feeding on euphausiid eggs were $30 \mathrm{~m}^{3} \mathrm{~d}^{-1}$ (Tables 4 \& 5), and we can check whether this rate is reasonable in several ways. First, it is comparable to clearance rates of $15.5 \mathrm{~m}^{3} \mathrm{~d}^{-1}$ reported by Purcell (2003) for smaller Cyanea capillata ingesting larvaceans in certain subregions of Prince William Sound, Alaska. Second, for stationary prey, encounter rates will depend upon encounter area (square of medusa's bell diameter) and the swimming speed of the predator (Gerritsen \& Strickler 1977). For example, a medusa of $20 \mathrm{~cm}$ diameter swimming $1 \mathrm{~cm} \mathrm{~s}^{-1}$ can sweep more than $100 \mathrm{~m}^{3}$ $\mathrm{d}^{-1}$. Capture efficiencies will be highest for stationary prey such as euphausiid eggs, and high capture to encounter ratios are likely $66 \%$ for slow-escaping prey in the laboratory, Sullivan et al. 1997). Finally, even with such high clearance rates, carbon analysis reveals relatively low daily rations for those C. fuscescens individuals collected during 2002 and 2003. For all stations, C. fuscescens ingested an average of $1.3 \%$ body $\mathrm{C} \mathrm{d}^{-1}$; when euphausiid eggs were present, the average was $1.9 \% \mathrm{~d}^{-1}$ (Table 3 ). These are not particularly high feeding rates from a carbon perspective and in fact, suggest that this population may be foodlimited. Other studies have estimated a $2 \% \mathrm{~d}^{-1}$ metabolic requirement (Sotje et al. 2007), or calculated $>3 \% \mathrm{~d}^{-1}$ body weight consumed (Brodeur et al. 2002).

Were conditions during this study typical of the region's upwelling season? Basin-scale forcing strongly influences both the biodiversity and biomass of copepod populations off the coast of Oregon (Hooff \& Peterson 2006). The year 2002 concluded a 4 -yr cool period in the California Current, associated with relatively low copepod biodiversity and high biomass. From the end of 2002 through 2006, however, the California Current warmed, and copepod biodiversity was high and biomass low. It is reasonable to expect that basinscale conditions related to El Niño or the Pacific Decadal Oscillation will affect not only copepods, but also influence local populations of gelatinous taxa. Thus, in a region subject to interannual and interdecadal variability in climatic conditions, and with ecosystem productivity so dependent upon physical forcing, data collected over several years are needed to confirm this study's predictions about the role of gelatinous predators.

Nevertheless, given spatial and temporal patterns of predators and prey, the population of Chrysaora fuscescens may routinely ingest euphausiid eggs at rates similar to those in August 2002. Medusae are typ- 
ically present in high densities along the inner shelf throughout summer months (Shenker 1984, Suchman \& Brodeur 2005), overlapping in space and time with peaks in egg densities following spawning events (100s to $\sim 1000$ eggs $\mathrm{m}^{-3}$ at a nearshore station off Newport, Oregon, Feinberg \& Peterson 2003). Larvae of both Euphausia pacifica and Thysanoessa spinifera are found nearshore during summer months relative to cross-shelf or offshore distribution of adults, and spawning may be concentrated close to shore to minimize advection of less mobile early stages (GómezGutiérrez et al. 2005). In fact, we probably underestimated the magnitude of predation on euphausiid eggs by other gelatinous predators that commonly occur in the region. These taxa, including ctenophores, hydromedusae (Mitrocoma cellularia, Aequorea spp.) and the scyphomedusa Aurelia labiata, also ingest euphausiid eggs (Larson 1987, this study, and C. Suchman unpubl. data).

What we cannot determine from this study is the proportion of euphausiid production removed by Chrysaora fuscescens in the Northern California Current. It is challenging to resolve euphausiid population dynamics because egg production is highly variable and not well understood (Feinberg et al. 2007). Cross-shelf distributions of adult euphausiids, as well as their eggs and larvae, depend upon complex circulation patterns related to the coastal upwelling process (GómezGutiérrez et al. 2005). Given high spatial and temporal overlap between medusae and euphausiid egg production on the Oregon shelf, however, we suggest that gelatinous predators may play a more important role in euphausiid population dynamics than previously recognized.

Our results should have broad implications for understanding upwelling ecosystems. This snapshot shows that where medusae are most abundant, they have the ability to deplete the standing stock of vulnerable prey. More focused research would be needed to link predation by gelatinous zooplankton to euphausiid population dynamics over seasonal or interannual time scales. In addition, gelatinous taxa such as Chrysaora fuscescens compete with fish and other nekton in the Northern California Current. Euphausiid eggs can be a large component of the diet of sardines and other forage fish (Emmett et al. 2005, Brodeur et al. 2008). Other nekton, such as salmonids, ingest laterstage euphausiids (Peterson et al. 1982, Brodeur \& Pearcy 1992). Analysis of multi-year, mesoscale sampling in the Northern California Current, in combination with diet studies of fish and medusae, should yield interesting results. Given the importance of euphausiids to fish and other top predators, and the potential for changes in abundance and distribution of both predator and prey taxa with changes in climate, we hope that other fisheries scientists and managers begin to monitor gelatinous zooplankton abundance and incorporate predation impacts within long-term studies and ecosystem models.

Acknowledgements. Thanks to L. Feinberg, T. Shaw, J. Burke, J. Gómez-Gutiérrez, J. Lamb, C. Morgan, Oregon Coast Aquarium, captains and crew of RV 'Elakha', RV 'New Horizon', and FV 'Frosti', for help with sampling or zooplankton identification. J. Costello, A. De Robertis, P. Ressler, B. Sullivan and anonymous reviewers provided comments on earlier drafts of the manuscript. This work was funded in part by an NRC Fellowship (to C.L.S.), the US GLOBEC Northeast Pacific Program, and the Bonneville Power Administration. This is contribution number 575 of the US GLOBEC Program.

\section{LITERATURE CITED}

Båmstedt U, Martinussen MB, Matsakis S (1994) Trophodynamics of the two scyphozoan jellyfishes, Aurelia aurita and Cyanea capillata, in western Norway. ICES J Mar Sci 51:369-382

Barz K, Hirche HJ (2005) Seasonal development of scyphozoan medusae and the predatory impact of Aurelia aurita on the zooplankton community in the Bornholm Basin (central Baltic Sea). Mar Biol 147:465-476

Behrends G, Schneider G (1995) Impact of Aurelia aurita medusae (Cnidaria, Scyphozoa) on the standing stock and community composition of mesozooplankton in the Kiel Bight (western Baltic Sea). Mar Ecol Prog Ser 127:39-45

Brodeur RD, Pearcy WG (1992) Effects of environmental variability on trophic interactions and food web structure in a pelagic upwelling ecosystem. Mar Ecol Prog Ser 84: 101-119

Brodeur RD, Sugisaki H, Hunt GL (2002) Increases in jellyfish biomass in the Bering Sea: implications for the ecosystem. Mar Ecol Prog Ser 233:89-103

Brodeur RD, Suchman CL, Reese DC, Miller TW, Daly EA (2008) Spatial overlap and trophic interactions between pelagic fish and large jellyfish in the northern California Current. Mar Biol (in press)

Brooks JL, Dodson SI (1965) Predation, body size, and composition of plankton. Science 150:28-35

Costello JH, Colin SP (1994) Morphology, fluid motion, and predation by the scyphomedusa Aurelia aurita. Mar Biol 121:327-334

Emmett RL, Brodeur RD, Miller TW, Pool SS, Krutzikowsky GK, Bentley PJ, McCrae J (2005) Pacific sardine (Sardinops sagax) abundance, distribution and ecological relationships in the Pacific Northwest. Calif Coop Ocean Fish Invest Rep 26:122-143

Fancett MS, Jenkins GP (1988) Predatory impact of scyphomedusae on ichthyoplankton and other zooplankton in Port Phillip Bay. J Exp Mar Biol Ecol 116:63-77

Feinberg LR, Peterson WT (2003) Variability in duration and intensity of euphausiid spawning off central Oregon, 1996-2001. Prog Oceanogr 57:363-379

Feinberg LR, Shaw CT, Peterson WT (2007) Long-term laboratory observations of Euphausia pacifica fecundity: a comparison of two geographic regions. Mar Ecol Prog Ser 341:141-152

Fields DM, Yen J (1997) The escape behavior of marine copepods in response to a quantifiable fluid mechanical disturbance. J Plankton Res 19:1289-1304 
Gerritsen J, Strickler JR (1977) Encounter probabilities and community structure in zooplankton: a mathematical model. J Fish Res Board Can 34:73-84

Gómez-Gutiérrez J (2003) Comparative study of the dynamic population, secondary productivity, and reproductive ecology of the euphausiids Euphausia pacifica and Thysanoessa spinifera in the Oregon upwelling region. $\mathrm{PhD}$ dissertation, Oregon State University, Corvallis, OR

Gómez-Gutiérrez J, Peterson WT, Miller CB (2005) Crossshelf life-stage segregation and community structure of the euphausiids off central Oregon (1970-1972). DeepSea Res II 52:289-315

Graham WM, Kroutil RM (2001) Size-based prey selectivity and dietary shifts in the jellyfish, Aurelia aurita. J Plankton Res 23:67-74

Hansson LJ, Kiørboe T (2006) Effect of large gut volume in gelatinous zooplankton: ingestion rate, bolus production and food patch utilization by the jellyfish Sarsia tubulosa. J Plankton Res 28:937-942

Hooff RC, Peterson WT (2006) Copepod biodiversity as an indicator of changes in ocean and climate conditions of the northern California current ecosystem. Limnol Oceanogr 51:2607-2620

Keister JE, Houde ED, Breitburg DL (2000) Effects of bottomlayer hypoxia on abundances and depth distributions of organisms in Patuxent River, Chesapeake Bay. Mar Ecol Prog Ser 205:43-59

Larson RJ (1987) Trophic ecology of planktonic gelatinous predators in Saanich Inlet, British Columbia: diets and prey selection. J Plankton Res 9:811-820

Lynam CP, Hay SJ, Brierley AS (2004) Interannual variability in abundance of North Sea jellyfish and links to the North Atlantic Oscillation. Limnol Oceanogr 49:637-643

Lynam CP, Gibons MJ, Axelsen BE, Sparks CAJ, Coetzee J, Heywood BG, Brierley AS (2006) Jellyfish overtake fish in a heavily fished ecosystem. Curr Biol 16:R492-R493

Martinussen MB, Båmstedt U (1995) Diet, estimated daily food ration and predator impact by the scyphozoan jellyfishes Aurelia aurita and Cyanea capillata. In: Skjoldal HR, Hopkins C, Erikstad KE, Leinaas HP (eds) Ecology of fjords and coastal waters. Elsevier Science, Amsterdam, p $127-145$

Martinussen MB, Båmstedt U (1999) Nutritional ecology of gelatinous planktonic predators. Digestion rate in relation to type and amount of prey. J Exp Mar Biol Ecol 232: $61-84$

Mills CE (2001) Jellyfish blooms: are populations increasing globally in response to changing ocean conditions? Hydrobiologia 451:55-68

Möller H (1984) Reduction of a larval herring population by jellyfish predator. Science 224:621-622

Pearre S (1982) Estimating prey preference by predators: uses of various indices, and a proposal of another based on $\chi^{2}$. Can J Fish Aquat Sci 39:914-923

Peterson WT, Brodeur R, Pearcy WG (1982) Diets of juvenile salmon in the Oregon upwelling zone in June 1979. Fish Bull 80:841-851

Peterson WT, Keister JE, Feinberg LR (2002) The effects of the 1997-1999 El Niño/La Niña events on hydrography and

Editorial responsibility: Kenneth Sherman, Narragansett, Rhode Island, USA zooplankton off the central Oregon coast. Prog Oceanogr 54:381-398

Peterson WT, Emmett R, Goericke E, Venrick A and others (2006) The state of the California Current, 2005-2006: warm in the north, cool in the south. Calif Coop Ocean Fish Invest Rep 47:30-74

Purcell JE (2003) Predation on zooplankton by large jellyfish, Aurelia labiata, Cyanea capillata and Aequorea aequorea, in Prince William Sound, Alaska. Mar Ecol Prog Ser 246: $137-152$

Purcell JE (2005) Climate effects on formation of jellyfish and ctenophore blooms. J Mar Biol Assoc UK 85:461-476

Purcell JE, Cresswell FP, Cargo DG, Kennedy VS (1991) Differential ingestion and digestion of bivalve larvae by the scyphozoan Chrysaora quinquecirrha and by the ctenophore Mnemiopsis leidyi. Biol Bull 180:103-111

Purcell JE, Malej A, Benović A (1999) Potential links of jellyfish to eutrophication and fisheries. In: Malone TC, Malej A, Harding LW Jr, Smodlaka N, Turner ER (eds) Ecosystems at the land-sea margin: drainage basin to coastal sea. Coastal and Estuaries Studies 55. American Geophysical Union, Washington, DC, p 241-263

Ross RM (1982) Energetics of Euphausia pacifica II. Complete carbon and nitrogen budgets at $8^{\circ}$ and $12^{\circ} \mathrm{C}$ throughout the life span. Mar Biol 68:15-23

Shenker JM (1984) Scyphomedusae in surface waters near the Oregon coast, May-August 1981. Estuar Coast Shelf Sci 19:619-632

Shenker JM (1985) Carbon content of the neritic scyphomedusa Chrysaora fuscescens. J Plankton Res 7:169-173

Sotje I, Tiemann H, Bamstedt U (2007) Trophic ecology and the related functional morphology of the deepwater medusa Periphylla periphylla (Scyphozoa, Coronata). Mar Biol 150:329-343

Sparks C, Buecher E, Brierley AS, Axelsen BE, Boyer H, Gibbons MJ (2001) Observations on the distribution and relative abundance of the scyphomedusan Chrysaora hysoscella (Linné, 1766) and the hydrozoan Aequorea aequorea (Forskål, 1775) in the northern Benguela ecosystem. Hydrobiologia 451:275-286

Suchman CL, Brodeur RD (2005) Abundance and distribution of large medusae in surface waters of the northern California Current. Deep-Sea Res II 52:51-72

Suchman CL, Sullivan BK (2000) Effect of prey size on vulnerability of copepods to predation by the scyphomedusae Aurelia aurita and Cyanea sp. J Plankton Res 22:2289-2306

Sullivan BK, Suchman CL, Costello JH (1997) Mechanics of prey selection of the scyphomedusa Aurelia aurita. Mar Biol 130:213-222

Titelman J, Hansson LJ (2006) Feeding rates of the jellyfish Aurelia aurita on fish larvae. Mar Biol 149:297-306

Uye S (1982) Length-weight relationships of important zooplankton from the inland Sea of Japan. J Oceanogr Soc Jpn 38:149-158

Uye S, Shimauchi H (2005) Population biomass, feeding, respiration and growth rates, and carbon budget of the scyphomedusa Aurelia aurita in the inland Sea of Japan. J Plankton Res 27:237-248

Submitted: October 2, 2005; Accepted: October 11, 2007 Proofs received from author(s): March 17, 2008 